\title{
THE IMPACT OF ICTS ON AGRICULTURAL PRODUCTION IN BANGLADESH: A STUDY WITH FOOD CROPS
}

\author{
Susmita Das ${ }^{* 1}$,M. Nasiruddin Munshi ${ }^{2}$ and W. Kabir ${ }^{3}$ \\ ${ }^{1}$ Senior Documentation Officer, Bangladesh Agricultural Research Council, Dhaka-1215 \\ ${ }^{2}$ Department of Information Science and Library Management, University of Dhaka, Bangladesh \\ ${ }^{3}$ Former Executive Chairman, Bangladesh Agricultural Research Council, Dhaka-1215
}

\begin{abstract}
Agricultural development cannot be understood without the use of modern technologies like Information and Communication Technologies (ICTs). The recent developments in ICTs offer a unique opportunity to bring the production enhancing tools and technologies to the growers with much cost effective manner. Worldwide, many studies were published on the role of application of ICTs in agricultural production. However, only a few studies were carried out to know the impact of ICT based service delivery system on agricultural production aspects in Bangladesh. Therefore an attempt has been made to find the impact of ICTs on agricultural production, especially in the food crops. Using a randomised survey with a questionnaire, interviews and focus group discussion, a study was carried out with a sample of 1990 farmers from a population comprises farmers all over the country. The findings from the study after counterfactual analysis and difference in differences analysis as well showed that with the application and use of ICTs, agricultural production was accelerated which was evident from the degree of increase of ICT to that of counterfactual is 0.49 and proved that the Boro rice production from the ICT based service area has increased more than that of non-ICT based area.
\end{abstract}

Keywords: Information communication technologies, ICTs, counterfactual, agricultural production, difference in difference, impact analysis.

\section{INTRODUCTION}

Agricultural data, information and knowledge generated by the farmers themselves by interacting with fellow farmers influence agricultural productivity in various ways. It can help farmers take the right decision about the land, labour, variety, fertilizer, capital and management. Agricultural productivity can be arguably

\footnotetext{
* Corresponding author email:susmitabarc@gmail.com
} 
improved by relevant, reliable and useful information and knowledge (Demiryurek et al., 2008). The present famous acronym ICT serves best means to provide information to the stakeholders like farmers. The global attention has come to the impact of ICTs on agriculture as its buzz rings that ICTs should be hailed to be integrated with agriculture to boost its production. The ICTs have shown evidence for easier access to agricultural development to the standard livelihood of farmers (Roy et al., 2003). The computers, internet, geographical information systems, mobile phones, as well as traditional media such as radio or TV stimulate participation and enhance the value of productivity. In this backdrop, an attempt was made to study and examine the impact of ICTs on agricultural production in Bangladesh.

Technologies composed of ICTs are the blessing to agriculture as they provide the farmers with data, information and knowledge with which they can empower themselves with modern agricultural technology and act accordingly for increasing the production of higher value crops, reduction in expenses of production, increase in selling price, less use of pesticides for vegetables on their farms. As mentioned, it is now proved that the use of ICT has become increasingly integrated to address the farmers' information need in all over the world (Islam \& Islam, 2008), the ICTs have transferred most important information about agriculture in developed countries. The developing countries, which are now being connected with developed nations with the connectivity and are now able to get the access to the latest information and technologies regarding weather, natural resources and other related information (Rao, 2007). The term 'Information and Communication Technologies' could be used for a multitude of stand including telephone, television, video, voice information systems, and fax (Warren, 2002). As Mannan and Bose (1998) rightly maintained that the ICTs have a key role in Agri-food sectors to provide a fast information and knowledge about agriculture through all over the world, Kiplang'at (1999) postulated that dissemination of relevant information to the farming communities can facilitate the effective adoption of agricultural inputs, decision making about markets and adoption of scientific methods. However, lack of dissemination of information across the agricultural supply chain is a major concern in the developing world. Information and communication technologies have potential to disseminate the agricultural systematic information among smallholder farmers. Similarly the mobile phones, television, internet and radio have the facility to transfer related and timely information that helps to make decisions to use resources in the most productive and profitable way (Ekbia and Evans, 2009; Ommani and Chizari, 2008). Thus, it could be said that the ICTs played very effective role in the agricultural development and in the decision making of farmers' communities in different countries (Cash, 2001; Galloway and Mochrie, 2005; Opara, 2008; Taragola and Van Lierde, 2010). ICTs are a real source of information and knowledge for people, including farmers and reduced the distance between different communities of the world (Herselman, 2003). ICTs have brought significant changes in agriculture development and transfer information and knowledge through various technologies among farmers (Birkhaeuser et al., 1991). 
The present study examines the impact of ICTs on production measuring the findings of the data. It investigates farmers' proper access and utilization of agricultural information towards increased production of various crops. The study further examines the potential of the farmers of both groups in a production gain correlating their present production with that of the past. The comparative study of their production as well as their ICT use is shown here. The main purpose of the study was to draw a line of production variables between two certain groups of farmers in Bangladesh. The result is intended to be built on the experiences of both ICT and non-ICT service area in farming in ecological zones. Famers' production cost, production of different crops and seasons are serially shown in different tables. The impact of ICT on farmers' production reflects their annual profit or income.

\section{MATERIALS AND METHODS}

The study was conducted in all administrative divisions of Bangladesh- Dhaka, Chittagong, Rajshahi, Khulna, Barisal, Rangpur and Sylhet and it covered almost 42 out of 64 districts $(65.63 \%)$ of ICT area and 39 districts $(69.94 \%)$ from non-ICT area under direct supervision of the researcher. Districts were purposefully selected to take care of healthy proportion of ICT dependent areas as well as non-ICT based traditional farming areas. Areas range from Southeast Rangamati to Northeast Netrokona and South-west Satkhira to Northeast Sylhet. The population comprises farmers all over the country and it is categorized into two types. One type was ICT supported farmers who responded to the uses and applications of ICT in farming. Another set of respondents was non-ICT supported farmers. One thousand nine hundred and ninety are the sample size of the study. Out of this, 1170 are found ICT based and 820 are non-ICT based farmers. The population comprises farmers all over the country and it is categorized into two types- ICT supported farmers and non-ICT supported farmers. Random sampling was applied along with re-call method. Two sets of questionnaire were formulated for two groups of farmers- ICT service area and non-ICT one. Formal and informal interviews were held to explore the views, experiences, beliefs and motivations of individual participants. Few focus group discussions (FGDs) were also conducted for generating information on collective views and the meanings that lie behind those views. Extensive field visits in the ICT and non-ICT areas were made. The data of two consecutive years were collected from the farmers through recall method. These periods are called the baseline year (2012) and the follow-up year (2014). The original data were collected in 2014 from the respondents of two service areas. For the impact analysis, the Difference-inDifferences (DiD) analysis model which estimates a degree of treatment effect of a policy change for two groups and for two time periods (Ashenfelter and Card, 1985) are used to compare the production of two service areas through counterfactual. The counterfactual analysis, which compares what actually happened and what would have happened in the absence of an intervention, was carried out to know the actual impact of ICTs on production aspects of the food crops. Reliability for internal 
consistency is calculated using the Cronbach's (1970) Alpha Coefficient. The findings are graphed to allow a clear view of understanding at a glance. The two categories of service areas (ICT) and (non-ICT) respectively, have been collaborating to allow for comparative discussion of the results.

\section{RESULT AND DISCUSSION}

Different types of crops are cultivated in different seasons. While in Rabi season, the production of Boro rice, wheat, maize, mustard, pulses, sugarcane, vegetables and onion are cultivated, in Kharif-1, rice (Broadcast), rice (Aus), jute, different types of vegetables, and in Kharif-2, rice (T-Aman), maize, onion, and many types of vegetables are cultivated. For the study, the production of these crops is taken as dependent variable that changes by the influence of ICT use in the cultivation process. During the study, it was found that the follow-up production of both groups has increased, but the rate of increase of ICT farmers is higher than that of non-ICT service areas.

Table 1. Total production of rice (Aus, Aman and Boro) during 2006-07 to 2014-15

\begin{tabular}{l|r|r|r|r|r|r|r|r|r}
\hline $\begin{array}{c}\text { Food } \\
\text { grains }\end{array}$ & $\begin{array}{c}2006- \\
07\end{array}$ & $\begin{array}{c}2007- \\
08\end{array}$ & $\begin{array}{c}2008- \\
09\end{array}$ & $\begin{array}{c}2009- \\
10\end{array}$ & $\begin{array}{c}2010- \\
11\end{array}$ & $\begin{array}{c}2011- \\
12\end{array}$ & $\begin{array}{c}2012- \\
13\end{array}$ & $\begin{array}{c}2013- \\
14\end{array}$ & $\begin{array}{c}2014-15 \\
\text { (Target) }\end{array}$ \\
\hline Aus & 15.12 & 22.93 & 21.00 & 21.33 & 23.32 & 23.32 & 21.58 & 23.26 & 23.28 \\
Aman & 108.41 & 110.02 & 112.25 & 127.91 & 127.98 & 127.98 & 128.97 & 130.23 & 131.90 \\
Boro & 159.90 & 186.77 & 182.87 & 185.25 & 186.17 & 187.59 & 187.78 & 190.07 & 189.77 \\
Total Rice & 283.43 & 319.76 & 326.12 & 334.03 & 335.41 & 338.90 & 338.33 & 343.56 & 388.95 \\
Wheat & 7.25 & 9.56 & 9.58 & 9.69 & 9.72 & 9.95 & 12.55 & 13.02 & 13.33 \\
Maize & 8.99 & 23.69 & 11.37 & 8.87 & 15.52 & 19.54 & 21.78 & 25.16 & 25.21 \\
Total & 299.67 & 352.93 & 347.07 & 358.12 & 360.65 & 368.65 & 372.66 & 381.74 & 383.49 \\
\hline
\end{tabular}

The total production of rice (Aus, Aman and Boro) has increased to some extent from previous years (Table 1). The production of Aus is 23.26 in 2013-14 but it was 15.12 MT in 2006-2007. The production of Aman is 130.23 in 2013-14 whereas it was 108.41 MT in 2006-2007. The production of Boro is 190.07 in 201415. On the other hand, it was 159.90 MT in 2006-2007. The general picture of production performance of various crops by baseline (2012) and follow-up (2014) were given in the following manner.

The ICT tools are regarded as the best means of communication which play a vital in making agriculture more efficient and effective. When we talk about 'eagriculture', it largely depends on the proper application of these ICT tools. Radio, Television, Mobile and Computer are regarded as the ICT tools in both the service 
areas of the present study. In the study it was found that the TV is a very common tool that is available in almost every house of all farmers. However, the computer is rarely used by farmers in the non-ICT service area. All the four tools are not equally used by the farmers in the same area. The use and holding of ICT tools differ from area to area.

Table 2. ICT tools by service areas

\begin{tabular}{lcrrrrrr}
\hline \multirow{2}{*}{ Assets } & & \multicolumn{6}{c}{ Service Area } \\
\cline { 3 - 8 } & & \multicolumn{2}{c}{ ICT } & \multicolumn{2}{c}{ Non-ICT } & \multicolumn{2}{c}{ Total } \\
\cline { 3 - 8 } & & \multicolumn{1}{c}{ No. } & \multicolumn{1}{c}{$\%$} & \multicolumn{1}{c}{ No. } & \multicolumn{1}{c}{$\%$} & \multicolumn{1}{c}{ No. } & $\%$ \\
\hline Radio & No & 620 & 47.00 & 655 & 20.00 & 1275 & 64.07 \\
& Yes & 550 & 53.00 & 165 & 80.00 & 715 & 35.93 \\
Mobile & No & 35 & 3.00 & 205 & 25.00 & 240 & 12.06 \\
& Yes & 1135 & 97.00 & 615 & 75.00 & 1750 & 87.94 \\
\multirow{4}{*}{ Television } & No & 468 & 40.00 & 492 & 40.00 & 960 & 48.24 \\
& Yes & 702 & 60.00 & 328 & 60.00 & 1030 & 51.76 \\
& No & 770 & 65.81 & 730 & 89.02 & 1500 & 75.38 \\
& Yes & 400 & 34.19 & 90 & 10.98 & 490 & 24.62 \\
\hline
\end{tabular}

Now mobile is the easy and quick means of ICT communicative tool. It was found that 1855 farmers $(93.22 \%$ ) (out of 1990 respondents) have at least one set of mobile phone (Table 2).

Of them, $65 \%$ belong to ICT and 35\% belong to non-ICT based farmers. More farmers are seen holding a mobile phone in the ICT service area. Television is next to the frequency of mobile phone. It is held by $77.89 \%$ of the total farmers where ICT possess $65 \%$ and non-ICT $35 \%$. The number of radio and computer is far less than those of TV and mobile. Yet, the number of farmers using computers is outnumbered by that of radio. Out of the total farmers, $31.41 \%$ have radio sets and only $24.62 \%$ have a computer. It is important to find in ICT area more farmers use these ICT tools.

Data on the production aspects were analysed and correlated with the ICT and non-ICT groups and with the counterfactual conditionals which take the generic form of difference in differences (Figure 1.) was carried out. 


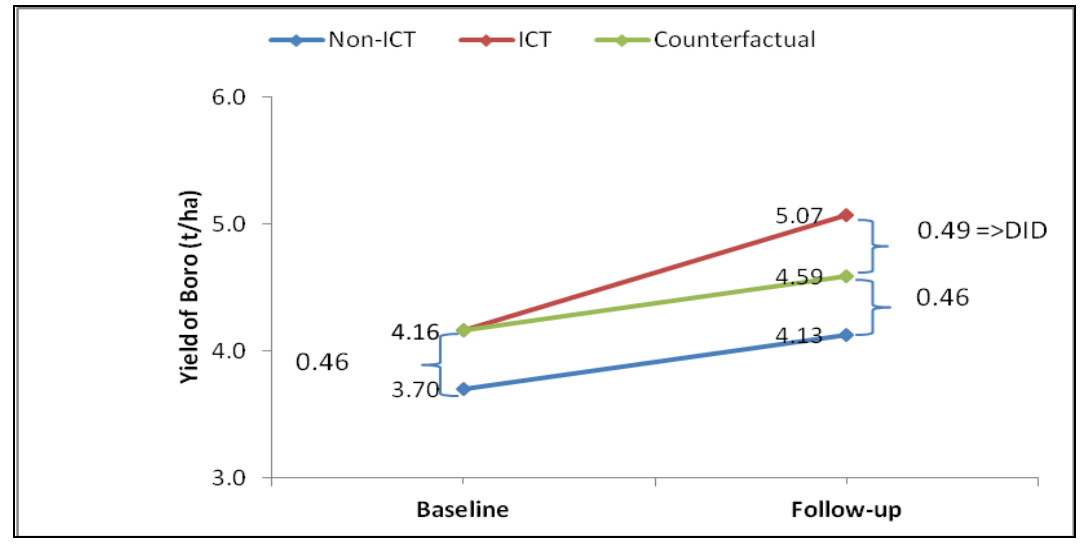

Figure 1. Production performance of Boro Rice by baseline and follow-up

The results revealed that the difference of Boro rice production from non-ICT based service area that DiD not actually occur. It is argued here that such propositions play a necessary and fundamental role in the whole effects of ICT on a production system. Here it is found that the follow-up (2014) production of both ICT and non-ICT areas has gradually increased, but to the greatest extent, the increase rate of the ICT service area is higher than that of non-ICT service area. The figure (1) indicates that the follow-up production of non-ICT based area is higher by 0.43 than that of baseline production (2012). Here it is proved that the baseline production of non-ICT is $3.70 \mathrm{MT}$ and that, of ICT and the counterfactual is 4.16 (MT). The follow up of the counterfactual is 4.59 MT but follow-up production of ICT is 5.07 (MT). The degree of increase of ICT is so high that it exceeds to the counterfactual by 0.49 (Figure 1). Therefore, it is significantly proved that the Boro rice production from the ICT based service area has increased more than that of non-ICT based area.

Table 3. Production performance of Boro rice by baseline (2012) and follow-up (2014)

\begin{tabular}{|c|c|c|c|c|}
\hline \multirow[t]{2}{*}{ Parameters } & \multicolumn{2}{|c|}{ Un-standardized coefficients } & \multirow[t]{2}{*}{$\mathrm{T}$} & \multirow[t]{2}{*}{ Sig. } \\
\hline & B & Std. Error & & \\
\hline (Constant) & 3.70 & 0.09 & 41.04 & 0.00 \\
\hline Treatment (Trt) & 0.46 & 0.08 & 5.64 & 0.00 \\
\hline Time & 0.43 & 0.09 & 4.66 & 0.00 \\
\hline Interaction between $\operatorname{Trt} \mathrm{x}$ time & 0.49 & 0.06 & 7.89 & 0.00 \\
\hline Dependent variable: yield of B & $\left.a^{-1}\right)$ & & & \\
\hline
\end{tabular}

The counterfactual or potential outcome through the use of 'Difference in Differences' (DiD) reflects the perspective weaker treatment of non-ICT service area 
and stronger treatment of the ICT service area (Table 3). The follow-up production of ICT and non-ICT farmers is higher than that of the baseline one. Therefore, the research result is clear that the use of ICT influences more to the increasing of the production of the respective area.

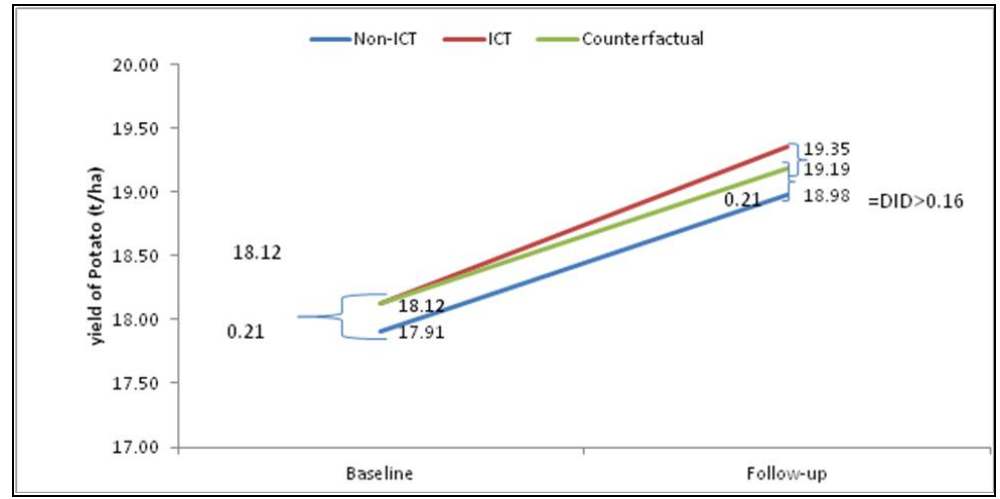

Figure 2. Production performance of potato by baseline and follow-up

The counterfactual of the production performance of potato (Figure 2) shows the different amount of potato production in non-ICT service area. Through the counterfactual, the fundamental scenario of potato production in non- ICT service area appears to be. Here it is found that the follow-up production of both ICT and non-ICT areas has gradually increased. It indicates that the follow-up production of non-ICT based area is more than that of baseline production. Here it is also noticed that the baseline production of ICT and baseline counterfactual and ICT production is 18.12 MT but the follow-up production of counterfactual and ICT is 19.19 MT and 19.35 MT respectively. The degree of Follow-up increase in the ICT service area is higher and it exceeds to the counterfactual by 0.16 MT (Figure 2).

Therefore, it is significantly proved that the potato production from the ICT service area has increased more than that of non-ICT area.

Table 4. Production performance of Rabi (potato) by baseline (2012) and follow-up (2014)

\begin{tabular}{|c|c|c|c|c|}
\hline \multirow[t]{2}{*}{ Parameters } & \multicolumn{2}{|c|}{ Un-standardized Coefficients } & \multirow[t]{2}{*}{$\mathrm{T}$} & \multirow[t]{2}{*}{ Sig. } \\
\hline & $\mathrm{B}$ & Std. Error & & \\
\hline (Constant) & 17.91 & 0.00 & $11,435.81$ & 0.00 \\
\hline Treatment (Trt) & 0.21 & 0.00 & 105.41 & 0.00 \\
\hline Time & 1.07 & 0.00 & 491.73 & 0.00 \\
\hline Trt $x$ Time & 0.16 & 0.00 & 59.51 & 0.00 \\
\hline Dependent Variable: Potato $\left(\mathrm{t} \mathrm{ha}^{-1}\right)$ & & & & \\
\hline
\end{tabular}


The table 4 shows that the counterfactual or potential outcome reflects the perspective weaker treatment of non-ICT service area and stronger treatment of the ICT service area. The result reveals that the use of ICT influences to increase the production of the farmers, though the baseline of non-ICT is higher than that of its follow up production.

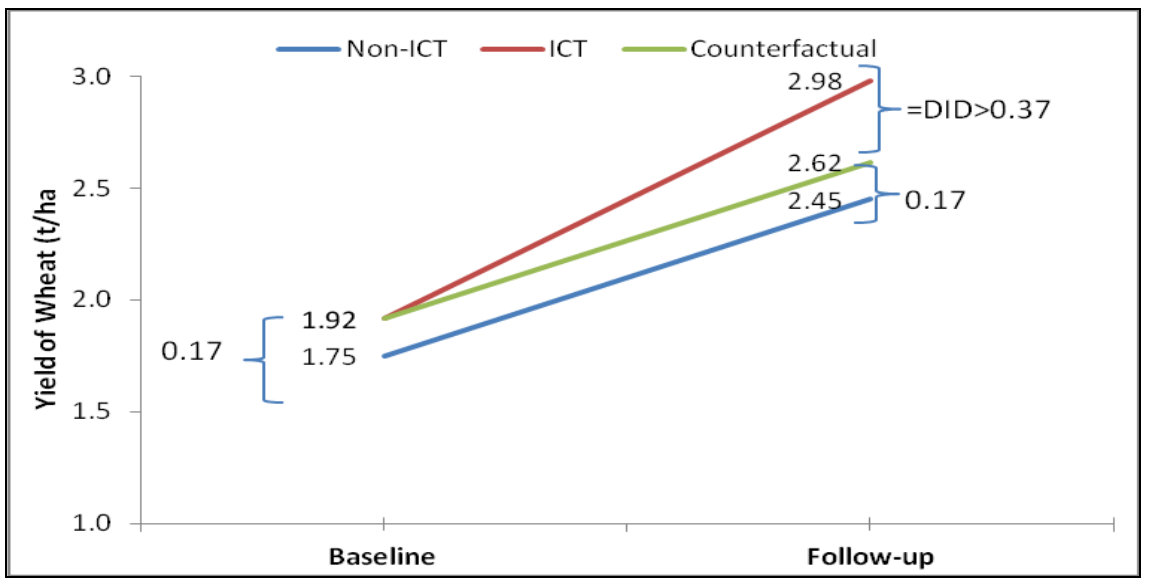

Figure 3. Production performance of Wheat by baseline and follow-up

The figure 3 indicates that the follow-up wheat production of non-ICT based area is higher by 0.7 than that of baseline production (2012). Here it is noticed that the baseline wheat production of non-ICT 1.75 and that of ICT and the counterfactual is 1.92 (MT). The follow up of the counterfactual is 2.62 but follow-up production of ICT is 2.98 (MT). The degree of increase of ICT is so high that it exceeds to the counterfactual by 0.37 MT (Figure 3). Therefore, the findings prove that the wheat production from the ICT based service area has increased than the increase of wheat production of non-ICT based area.

Table 5. Production performance of wheat by baseline (2012) and follow-up (2014)

\begin{tabular}{|c|c|c|c|c|}
\hline \multirow[t]{2}{*}{ Parameters } & \multicolumn{2}{|c|}{ Un-standardized Coefficients } & \multirow[t]{2}{*}{$\mathrm{T}$} & \multirow[t]{2}{*}{ Sig. } \\
\hline & $\mathrm{B}$ & Std. Error & & \\
\hline (Constant) & 1.75 & 0.16 & 11.11 & 0.00 \\
\hline Treatment & 0.17 & 0.02 & 8.60 & 0.00 \\
\hline Time & 0.70 & 0.09 & 7.61 & 0.05 \\
\hline Trt $\mathrm{x}$ time & 0.37 & 0.07 & 5.03 & 0.06 \\
\hline
\end{tabular}


The table 5 shows that the counterfactual or potential outcome reflects the perspective weaker treatment of non-ICT service area and stronger treatment of the ICT service area. The follow-up production of non-ICT is lower than that of ICT farmers. Thus, it is clear that the use of ICT influences the increase in the production of the farmers.

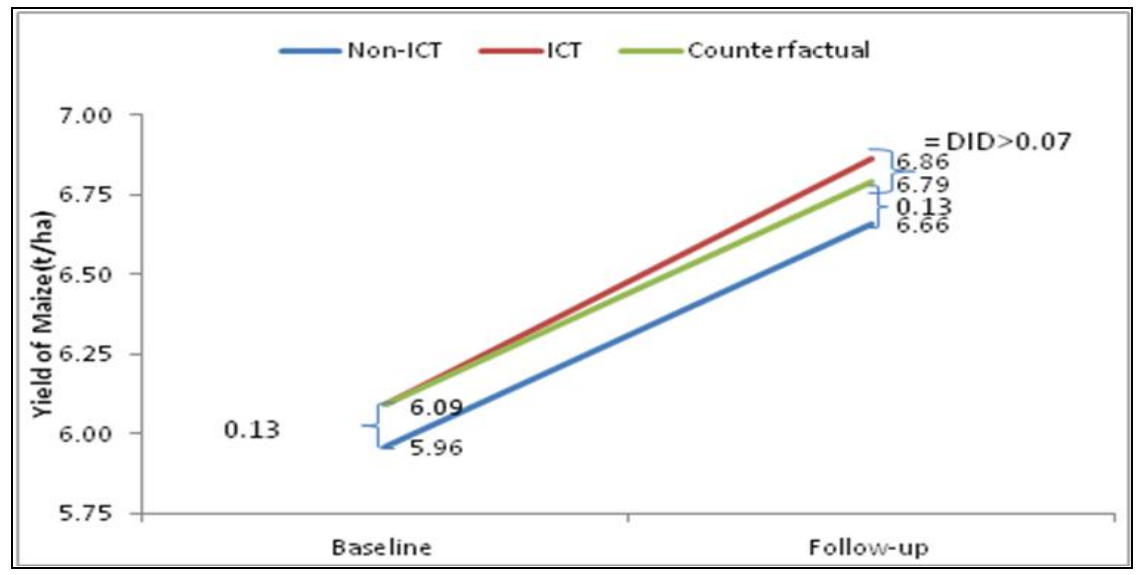

Figure 4. Production performance of Maize by baseline and follow-up

The figure (4) indicates that the degree of increase in maize production in the ICT area is higher and it exceeds to the counterfactual by 0.07 MT (Figure 4). The follow-up production of non-ICT based area is also higher by 0.7 than that of baseline production (2012). Here it is obviously clear that the baseline production of non-ICT is 5.96 and that of ICT and the counterfactual is 6.09 (MT). The follow-up of the counterfactual is 6.79 but follow-up maize production of ICT is 6.86 (MT). Therefore, it can significantly be mentioned that the maize production from the ICT service area has increased more than the increase of maize production of non-ICT area.

Table 6. Production performance of maize by baseline (2012) and follow-up (2014)

\begin{tabular}{|c|c|c|c|c|}
\hline \multirow[t]{2}{*}{ Parameter } & \multicolumn{2}{|c|}{ Un-standardized coefficients } & \multirow[t]{2}{*}{$\mathrm{T}$} & \multirow[t]{2}{*}{ sig. } \\
\hline & $\mathrm{B}$ & Std. Error & & \\
\hline (Constant) & 5.96 & 0.03 & 233.33 & 0.00 \\
\hline Treatment (Trt) & 0.13 & 0.03 & 3.93 & 0.05 \\
\hline Time & 0.70 & 0.13 & 5.24 & 0.05 \\
\hline Trt $\mathrm{x}$ time & 0.07 & 0.04 & 1.49 & 0.07 \\
\hline Dependent variable: maize $\left(\mathrm{t} \mathrm{ha}^{-1}\right)$ & & & & \\
\hline
\end{tabular}


The table 6 points out that the counterfactual or potential outcome reflects the perspective weaker treatment of non-ICT service area and stronger treatment of the ICT service area. The follow-up production of ICT is much higher than that of nonICT farmers. Therefore, it is noticed that the use of ICT influences to increase the production of the farmers.

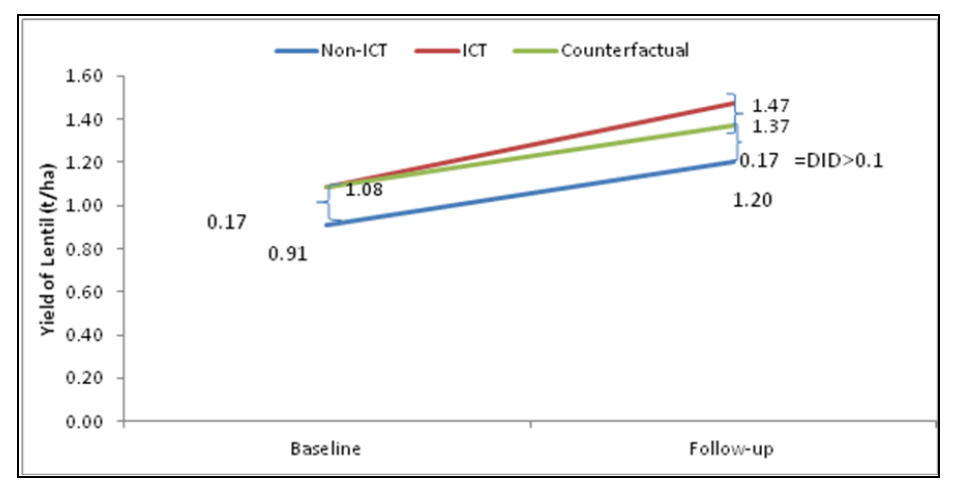

Figure 5. Production performance of pulse crop (Lentil) by baseline and follow-up

The table 6 points out that the counterfactual or potential outcome reflects the perspective weaker treatment of non-ICT service area and stronger treatment of the ICT service area. The follow-up production of ICT is much higher than that of nonICT farmers. Therefore, it is noticed that the use of ICT influences to increase the production of the farmers. The figure 5 shows that the follow up pulse (lentil) production of the counterfactual is 1.37 but that of ICT is 1.47 (MT). The increase of ICT is higher and it exceeds that of the counterfactual by 0.1 MT (Figure 5). The follow-up production of pulse (lentil) in non-ICT area is less by 0.29 than that of the baseline (2012) production. Here the analyzed results prove that the baseline pulse production of non-ICT $0.91 \mathrm{MT}$ and that, of ICT and the counterfactual is 1.08 (MT). Therefore, it proves that the pulse production from the ICT based service area has increased.

Table 7. Production performance of pulse (lentil) by baseline (2012) and follow-up (2014)

\begin{tabular}{lrrrrr}
\hline \multirow{2}{*}{ Parameter } & \multicolumn{2}{c}{ Un-standardised coefficients } & T & Sig. \\
\cline { 2 - 3 } & \multicolumn{1}{c}{ B } & \multicolumn{2}{c}{ Std. Error } & & \\
\cline { 2 - 3 } (Constant) & & 0.91 & 0.00 & 1291.37 & 0.00 \\
Treatment & 0.17 & 0.00 & 193.41 & 0.00 \\
Time & & 0.29 & 0.00 & 296.14 & 0.00 \\
Trt x time & & 0.10 & 0.00 & 77.95 & 0.00 \\
Dependent variable: pulse $\left(\mathrm{t} \mathrm{ha}^{-1}\right)$ & & & & & \\
\hline
\end{tabular}


The table 7 indicates that the counterfactual or potential outcome reflects the perspective weaker treatment of non-ICT service area and stronger treatment of the ICT service area. The non-ICT follow-up production is lower than that of ICT. Therefore, the findings prove that the proper use of ICTs has an impact on the pulse (lentil) produced in the two areas.

\section{CONCLUSION}

The study is envisaged to play a greater role in using the ICTs in farming, optimizing the uses of ICT tools and filling the gap that exists between the productions of the two service areas. The result of this empirical analysis suggests that ICTs play a significant role in enhancing agricultural production of two rice (Boro and Broadcast Aman), potato, wheat, maize and pulse (lentil). It also points out that the use of ICT tools remains a significant contributor to agricultural growth. The survey results show that the use of ICT tools varies from ICT service area to non-ICT one. There should be a focus on the spread and development of technology supported tools to use in farming and the farmers must be aware of the proper use of these tools. The use of ICT tools can be equalized both in the areas. The findings indicate that there is a production gap of the two category farmers and it could be minimized by using ICT tools more in farming of non-ICT service areas. A more organized approach to using ICT tools involving relevant knowledge based organizations is expected to bring better improvement to the total production system.

\section{REFERENCES}

Ashenfelter, O. and Card, D. 1985. Using the longitudinal structure of earnings to estimate the effect of training programs. Review of Economics and Statistics, 67: 648-660

Birkhaeuser, D., Evenson, R. E., and Feder, G. 1991. The economic impact of agricultural extension: A review. Economic Development and Cultural Change, 39: 607-650

Cash, D. W. 2001. In order to aid in diffusing useful and practical information: Agricultural extension and boundary organizations. Science Technology and Human Values, 26, $431-453$

Demiryurek, K., Erdem, H., Ceyhan, V., Atasever, S., and Uysal, O. 2008. Agricultural Information Systems and Communication networks: The case of dairy farmers in the Samsun Province of Turkey. Information Research, 13(2). Retrieved December 12, 2014 from http://www.informationr.net/ir/13-2/paper343.html

Ekbia, H. R. and Evans, T. P. 2009. Regimes of information: Land use, management, and policy. The Information Society, 25(5) 328-343

Galloway, L. and Mochrie, R. 2005. The use of ICT in rural firms: A policy orientated literature review. The Journal of Policy, Regulation and Strategy for Telecommunications, (7): 33-46 
Herselman, M. E. 2003. ICT in rural areas in South Africa: Various case studies. In Proceedings of Informing Science + Information Technology Education Joint Conference, 945-955

Islam, A. and Islam, M. 2008. Community information services in Bangladesh: A case study on community information Centre (CIC). Library Herald, Journal of the Delhi Library Association, 46(4): 225-280

Kiplang'at, J. 1999. An analysis of the opportunities for information technology in improving access, transfer and the use of agricultural information in the rural areas in Kenya, Library Management, 20(2):115-127

Mannan, S. M. and Bose, M. L. 1998. Resource sharing and information networking of libraries in Bangladesh: a study on user satisfaction. Malaysian Journal of Library \& Information Science, 3(2): 67-86

Ommani, A. R. and Chizari, M. 2008. Information dissemination system (IDS) based elearning in agricultural of Iran (perception of Iranian extension agents). World Academy of Science, Engineering and Technology, 38:468-472.Retrieved December 12, 2014 from http://www.waset.org/journals/waset/v38/v38-84.pdf

Opara, U. N. 2008. Agricultural Information sources used by farmers in Imo State, Nigeria. Information Development, 24(4): 289-295

Rao, N. H. 2007. A framework for implementing information and communication technologies in agricultural development in India. Technological Forecasting and Social Change, 74(4): 491-518

Roy, A. K., Srinivasacharylu, A and Samdrup Rigyal. 2003. Proceedings of the Regional Workshop on Role of Information and communication Technologies (ICT) for Poverty Alleviation in SAARC Countries, Dhaka, Bangladesh. 22-23 October 2003.SAARC Agricultural Information Centre (SAIC), New Airport Road, Farm gate, Dhaka. ISBN: 984-32-1026-3

Taragola, N. M. and Van Lierde, D. F. 2010. Factors affecting the internet behaviour of horticultural growers in Flanders, Belgium. Computers and Electronics in Agriculture, 70: 369-379

Warren, M. F. 2002. Adoption of ICT in agricultural management in the United Kingdom: The Intra-Rural Digital Divide. Agricultural Economics, 48(1): 1-8 